\title{
Cinnamon and Hop Extracts as Potential Immunomodulators for Severe COVID-19 Cases
}

\author{
Kurt Lucas $^{1 *}$, Janine Fröhlich-Nowoisky ${ }^{1}$, Nicole Oppitz ${ }^{1}$ and Maximilian Ackermann ${ }^{2,3}$ \\ ${ }^{1}$ Multiphase Chemistry Department, Max Planck Institute for Chemistry, Mainz, Germany, ${ }^{2}$ Institute of Pathology and \\ Molecular Pathology, Helios University Clinic Wuppertal, University of Witten/Herdecke, Wuppertal, Germany, ${ }^{3}$ Institute of \\ Functional and Clinical Anatomy, University Medical Center of the Johannes Gutenberg University Mainz, Mainz, Germany
}

Keywords: COVID-19, Ceylon cinnamon, hops, anti-inflammatory (activity), angiogenesis inhibition

\section{INTRODUCTION}

Despite intense focus, so far no effective treatment has been developed for severe cases of COVID-19. SARS-CoV-2 infection results in a multisystem hyperinflammatory syndrome with acute respiratory distress syndrome (ARDS), acute kidney failure, and cardiovascular and neurological complications (Wang et al., 2020). Severe cases of this condition are characterized by a "cytokine storm" and rampant inflammation (Renu et al., 2020; Ye et al., 2020). The hyperinflammation is associated with the generation and release of reactive oxygen and nitrogen species (ROS/RNS), which can further amplify inflammation (Lucas and Maes, 2013).

OPEN ACCESS

Edited by:

Linda Avesani,

University of Verona, Italy

Reviewed by:

Dayakar Venkata Badri,

Hill's Pet Nutrition, Inc., United States Jim Tokuhisa,

Virginia Tech, United States

*Correspondence:

Kurt Lucas

k.lucas@mpic.de

Specialty section:

This article was submitted to

Plant Metabolism and Chemodiversity,

a section of the journal

Frontiers in Plant Science

Received: 31 July 2020 Accepted: 02 February 2021

Published: 26 February 2021

Citation:

Lucas K, Fröhlich-Nowoisky J,

Oppitz N and Ackermann M (2021)

Cinnamon and Hop Extracts as

Potential Immunomodulators for

Severe COVID-19 Cases.

Front. Plant Sci. 12:589783.

doi: 10.3389/fp/s.2021.589783
Histopathological observation of COVID-19 has revealed diffuse alveolar damage with vascular endothelialitis, thrombosis, and intussusceptive angiogenesis (Ackermann et al., 2020). The angiocentric inflammation is not limited to the COVID-19-induced lung injury but also involves prolonged inflammation in other organs, such as the liver, brain, heart, or the gut (Ackermann et al., 2020; Wang et al., 2020). Any treatment that could limit the "cytokine storm”, reduce ROS/RNS production, and counteract the formation of thrombosis would be highly attractive, and, in the best-case scenario, such a treatment would additionally interfere with viral replication. Recently, a preliminary study reported that the administration of dexamethasone, a corticosteroid with anti-inflammatory effects, could elicit a $30 \%$ reduction in mortality for patients receiving invasive mechanical ventilation (Horby et al., 2020).

In a previous study, we screened a panel of 99 ethanolic herbal extracts for their anti-inflammatory properties. Hop (Humulus lupulus, cones) and Ceylon cinnamon (Cinnamomum verum alias C. zeylanicum, bark) extracts were found to elicit particularly drastic reductions in activation of the transcription factor NF- $\kappa \mathrm{B}$ (nuclear factor kappa-light-chain-enhancer of activated B cells), a key regulator of pro-inflammatory cytokines (Schink et al., 2018b).

The literature search was mainly performed in MedLine. In a first round, we looked for studies describing anti-inflammatory effects for Ceylon cinnamon, hops, and their major compounds. In a second approach, we then searched for clinical studies testing the efficacy of the plants in treating human disease.

\section{HOPS}

Hops, the seed cones of the plant Humulus lupulus from the family Cannabaceae, contain several pharmaceutically active compounds, such as humulone, lupulone, and xanthohumol (Gerhäuser, 2005; Knez Hrncic et al., 2019; Lin et al., 2019). Crude hop extracts as well as individual compounds have been described to exert anti-viral effects against several DNA and RNA viruses (Buckwold et al., 2004; Fuchimoto et al., 2013). For example, humulone, the most important bitter acid of hops, 
can suppress replication of the respiratory syncytial virus (RSV alias Human orthopneumovirus) in cell culture by disturbing the formation of viral filaments (Fuchimoto et al., 2013). Xanthohumol from hops showed synergistic effects with IFN- $\alpha$ in the treatment of bovine viral diarrhea virus (BVDV), and a combination of the two substances was more effective than IFN- $\alpha$ or xanthohumol alone (Zhang et al., 2010).

Scientific reports on the biological effects of hops and hop compounds are not limited to anti-viral properties; anti-bacterial activity, anti-fungal properties, and anti-malarial action have also been reported (Gerhäuser, 2005; Cermak et al., 2017; Weber et al., 2019). Lupulone and xanthohumol exhibit synergistic effects with selected clinically used antibiotics (Natarajan et al., 2008).

Hops also counteract inflammation; humulone can exert an anti-inflammatory effect on the TNF-induced expression of cyclooxygenase with effective doses that are in the same order of magnitude as dexamethasone (Yamamoto et al., 2000). Moreover, humulone can inhibit Toll-like receptor 4 (TLR4) and NF-кB signaling (Yamamoto et al., 2000; Fu et al., 2016; Schink et al., 2018b). In an animal model, topically applied humulone was shown to inhibit NF- $\mathrm{B}, \mathrm{AP}-1$, and mitogen-activated protein kinases (MAPKs) (Lee et al., 2007). Xanthohumol from hops was found to reduce the expression of IL-1 $\beta$, IL-6, IL- 8 , and TNF in virus-infected and LPS-stimulated porcine primary alveolar macrophages (Liu et al., 2019), and hop-derived humulone and lupulone were shown to mitigate the expression of IL-6 (Weber et al., 2019).

Hop extracts are further effective in counteracting oxidative and nitrosative stress; hop compounds were shown to mitigate neural nitric oxide synthase (nNOS) activity and 3-morpholinosydnonimine (SIN-1)-induced oxidation of LDL (Stevens et al., 2002). The transcription factor nuclear factor erythroid 2-related factor 2 (NRF2) is a key regulator of the expression of antioxidant genes (Yamamoto et al., 2018). Hop compounds and especially xanthohumol were shown to activate NRF2 in different studies (Dietz et al., 2005; Lee et al., 2011; Yao et al., 2015). A small, placebocontrolled, clinical study showed that a low-intake dose of 12 $\mathrm{mg}$ /day xanthohumol decreased oxidative stress-induced DNA damage (Ferk et al., 2016).

Xanthohumol was also shown to be effective in preventing thrombosis in animal models (Xin et al., 2017). In contrast to what has been observed for blood thinners, no increased bleeding was seen when the substance was administrated orally in two doses of $10 \mathrm{mg} / \mathrm{kg}$ xanthohumol per day for 60 days (Xin et al., 2017). The antioxidant effects of xanthohumol were also confirmed in this same study (Xin et al., 2017). Further, hops exert anti-fibrogenic effects in vitro, and specifically xanthohumol was shown to possess this property in vivo (Dorn et al., 2012; Saugspier et al., 2012).

\section{CEYLON CINNAMON}

The genus Cinnamomum belongs to the family Lauraceae and comprises more than 100 species in the NCBI Taxonomy Database. Here, we review specifically Ceylon cinnamon
(Cinnamomum verum alias C. zeylanicum, NCBI:txid128608), which we have used in our studies (Schink et al., 2018a,b; Ose et al., 2020). Generally, Chinese cassia or Chinese cinnamon (Cinnamomum cassia alias Cinnamomum aromaticum) is commercially sold as a spice for foods and does not represent a risk to human health per se (Oketch-Rabah et al., 2018). However, it can comprise high amounts of coumarin, which is highly hepatotoxic in higher doses. The German Federal Institute for Risk Assessment (BfR) therefore recommends that Cassia cinnamon with high coumarin content be consumed only at moderate levels. The differences between Ceylon cinnamon and Cassia have been reviewed recently (Oketch-Rabah et al., 2018).

Ethanolic extracts of Ceylon cinnamon possess antiinflammatory activity and antagonize TLR2 and TLR4 activation in a dose-dependent manner with minimal effects on viability in cell culture (Kanuri et al., 2009; Schink et al., 2018b). We identified several active compounds in these extracts, amongst others, trans-cinnamaldehyde, cinnamic acid, cinnamyl alcohol, cinnamyl methyl ether, p-cymene, methyl salicylate, 1-tetradecanol (myristyl alcohol), and benzoic acid. We found synergy among the anti-inflammatory properties of the different compounds: the efficacy of the complex mixture was greater than those of the pure active compounds of cinnamon (Schink et al., 2018a).

Cinnamaldehyde is an effective NRF2 inducer (Long et al., 2015) and acts in this way to detoxify ROS/RNS (Wondrak et al., 2010). Further, cinnamaldehyde can inhibit angiogenesis and metastasis via mitigation of the PI3K/Akt pathway (Patra et al., 2019). A specific inhibition of VEGFR2 kinase and of angiogenesis was shown for a water-based extract from Ceylon cinnamon (Lu et al., 2010).

In an animal model, an extract of Ceylon cinnamon was shown to protect the aorta from dexamethasoneinduced atherosclerosis and minimized the atherogenic risk (Nayak et al., 2017).

TABLE 1 | Active compounds from hops and Ceylon cinnamon.

\begin{tabular}{|c|c|c|}
\hline Plant & $\begin{array}{l}\text { Active } \\
\text { compound }\end{array}$ & References \\
\hline \multirow[t]{3}{*}{ Hops } & humulone & $\begin{array}{l}\text { Palamand and Aldenhoff, 1973; } \\
\text { Gerhäuser, 2005; Knez Hrncic et al., } \\
\text { 2019; Lin et al., } 2019\end{array}$ \\
\hline & lupulone & $\begin{array}{l}\text { Palamand and Aldenhoff, 1973; } \\
\text { Gerhäuser, 2005; Knez Hrncic et al., } \\
\text { 2019; Lin et al., } 2019\end{array}$ \\
\hline & xanthohumol & $\begin{array}{l}\text { Palamand and Aldenhoff, 1973; } \\
\text { Gerhäuser, 2005; Fu et al., 2016; } \\
\text { Knez Hrncic et al., 2019; } \\
\text { Lin et al., } 2019\end{array}$ \\
\hline \multirow[t]{3}{*}{ Ceylon cinnamon } & $\begin{array}{l}\text { trans- } \\
\text { cinnamaldehyde }\end{array}$ & $\begin{array}{l}\text { Schink et al., 2018a; Vasconcelos } \\
\text { et al., } 2018\end{array}$ \\
\hline & $\begin{array}{l}\text { cinnamic } \\
\text { acid }\end{array}$ & $\begin{array}{l}\text { Schink et al., 2018a; Vasconcelos } \\
\text { et al., } 2018\end{array}$ \\
\hline & $\begin{array}{l}\text { cinnamyl } \\
\text { alcohol }\end{array}$ & Schink et al., 2018a \\
\hline
\end{tabular}


TABLE 2 | Selected clinical studies on Ceylon cinnamon.

\begin{tabular}{|c|c|c|}
\hline $\begin{array}{l}\text { Disease/condition or } \\
\text { observed effect }\end{array}$ & Dosage form & References \\
\hline \multicolumn{3}{|l|}{ Ceylon Cinnamon } \\
\hline \multirow[t]{3}{*}{ type 2 diabetes } & $\begin{array}{l}\text { encapsulated } \\
\text { cinnamon power }\end{array}$ & $\begin{array}{l}\text { Khan et al., 2003; Mang } \\
\text { et al., 2006; Crawford, } \\
\text { 2009; Akilen et al., 2010; } \\
\text { Wainstein et al., 2011; } \\
\text { Talaei et al., 2017; } \\
\text { Mirmiran et al., 2019; Zare } \\
\text { et al., } 2019\end{array}$ \\
\hline & cinnamon extract & $\begin{array}{l}\text { Lu et al., 2012; } \\
\text { Ranasinghe et al., 2017a }\end{array}$ \\
\hline & $\begin{array}{l}\text { cinnamon in black } \\
\text { tea }\end{array}$ & Azimi et al., 2016 \\
\hline polycystic ovary syndrome & $\begin{array}{l}\text { encapsulated } \\
\text { cinnamon power }\end{array}$ & $\begin{array}{l}\text { Kort and Lobo, 2014; } \\
\text { Borzoei et al., 2018; } \\
\text { Hajimonfarednejad et al., } \\
2018\end{array}$ \\
\hline $\begin{array}{l}\text { dysmenorrhea (painful } \\
\text { periods) }\end{array}$ & & Jahangirifar et al., 2018 \\
\hline metabolic syndrome & & Gupta Jain et al., 2017 \\
\hline $\begin{array}{l}\text { migraine attacks and } \\
\text { inflammatory markers }\end{array}$ & & Zareie et al., 2020 \\
\hline $\begin{array}{l}\text { pharmacodynamic } \\
\text { properties and safety }\end{array}$ & & Ranasinghe et al., 2017b \\
\hline $\begin{array}{l}\text { postmenopausal type } 2 \\
\text { Diabetes }\end{array}$ & & $\begin{array}{l}\text { Vanschoonbeek et al., } \\
2006\end{array}$ \\
\hline $\begin{array}{l}\text { overweight or obese } \\
\text { pre-diabetic subjects }\end{array}$ & & Liu et al., 2015 \\
\hline $\begin{array}{l}\text { non-alcoholic fatty liver } \\
\text { disease }\end{array}$ & & Askari et al., 2014 \\
\hline $\begin{array}{l}\text { Ceylon cinnamon does not } \\
\text { affect postprandial plasma } \\
\text { glucose or insulin }\end{array}$ & & Wickenberg et al., 2012 \\
\hline $\begin{array}{l}\text { overweight or obese } \\
\text { subjects }\end{array}$ & cinnamon extract & Roussel et al., 2009 \\
\hline $\begin{array}{l}\text { effect on } \\
\text { electrocardiographic } \\
\text { parameters }\end{array}$ & & Pender et al., 2018 \\
\hline $\begin{array}{l}\text { perineal pain and healing of } \\
\text { episiotomy }\end{array}$ & & Mohammadi et al., 2014 \\
\hline Helicobacter pylori & & Nir et al., 2000 \\
\hline type 1 diabetes & cinnamon pill & Altschuler et al., 2007 \\
\hline overactive bladder & cinnamon patch & Chen et al., 2021 \\
\hline $\begin{array}{l}\text { postprandial (after meals) } \\
\text { capillary blood glucose level }\end{array}$ & cinnamon tea & Bernardo et al., 2015 \\
\hline
\end{tabular}

\section{RETRIEVED RESULTS FROM CLINICAL STUDIES}

We searched for clinical studies on Cinnamon using the search term "Ceylon Cinnamon OR Cinnamaldehyde," while for clinical studies on hops we used the search term "Humulone OR Lupulone OR Xanthohumol OR hops" (Tables 2, 3). For both search terms, we restricted the results to "Clinical Trial." For Cinnamon we obtained 123 hits, from which we excluded 57
TABLE 3 | Selected clinical studies on hops.

\begin{tabular}{lll}
\hline $\begin{array}{l}\text { Disease/condition } \\
\text { or observed effect }\end{array}$ & Dosage form & References \\
\hline
\end{tabular}

or observed effect

\section{Hops}

quality of sleep

Vigilance

menopausal

symptoms

appetite suppression

body fat

dental plaque

regrowth

clinical safety and

efficacy

self-reported depression, anxiety, and stress levels

overactive bladder standardized extracts of
Valeriana officinalis,
Passiflora incarnate, and Humulus lupulus

linolenic and linoleic acids Cornu et al., 2010 in association with Humulus lupulus extract. valerian/hop extract combination and hops

hop extract

hop tablets

hop flower extract suspended in canola oil matured hop extract

hop bract polyphenols

combination of iso-alpha acids from hops, rosemary, and oleanolic acid

dry hop extract

combination of seed oil Gauruder-Burmester et al., from Uromedic pumpkin, 2019

Rhus aromatica (bark extract, and hop cone extract)

intestinal conversion of dose of isoxanthohumol isoxanthohumol in 8-prenylnaringenin endothelial functions isomerized hop extract Tomita et al., 2017
Kyrou et al., 2017

Müller-Limmroth and Ehrenstein, 1977; Koetter et al., 2007; Dimpfel and Suter, 2008

Gerhard et al., 1996

Erkkola et al., 2010; van

Breemen et al., 2020

Aghamiri et al., 2016

Walker et al., 2019

Morimoto-Kobayashi et al., 2016; Suzuki et al., 2018

Shinada et al., 2007

Minich et al., 2007

Possemiers et al., 2006 hits, as cinnamon was not used to treat human disease in these studies. The ethanolic extract, as used in cell culture experiments, was not directly given to patients in any of the clinical studies. Rather, for the majority of clinical studies with Ceylon cinnamon, powder was administered in an encapsulated form; the clear advantage of administering Ceylon cinnamon in this way is that the formulation does not comprise ethanol. Since we cannot give here an appropriate dosage of cinnamon for the treatment of COVID-19, we refer to clinical studies that have used cinnamon to treat other conditions. Thirty of the clinical Cinnamon studies deal with diabetes, glucose levels, and insulin tolerance, five with polycystic ovary syndrome, and three with overweight and obesity. We could not find any clinical studies on "cytokine storms," but we hypothesize that the strong anti-inflammatory properties of Ceylon cinnamon may mitigate this complication. 
Ranasinghe et al. evaluated the safety of Ceylon cinnamon in healthy adults, concluding that there were no significant side effects and toxicity of Ceylon cinnamon for the dosages applied (Ranasinghe et al., 2017b).

When searching for hops and compounds found in hops, we obtained 92 hits for clinical studies, from which we excluded 50 as non-matching. This is because many hits refer to the verb "to hop," i.e., "to jump." Eight studies are linked to sleep disorders, six to adiposity and metabolic syndrome, six to menopause, and two clinical studies are on anti-bacterial effects. Often hops are given orally as an extract (water, oil), which is frequently administered in combination with other drugs such as valerian. One study concerns specifically the use of iso-alpha-acids from hops, which include humulone, to dampen inflammation in knee osteoarthritis (Hall et al., 2008).

Taken together, among the so-far performed clinical studies on Ceylon cinnamon and hops, we could not find any that specifically described efficacy in preventing the "cytokine storm" or sepsis. However, results from diverse cell culture experiments make it likely that hops and Ceylon cinnamon may exert these effects.

\section{DISCUSSION}

Both hop and cinnamon extracts have been shown to exert several anti-inflammatory functions (Yamamoto et al., 2000; Schink et al., 2018a,b). For instance, both can dampen the release of pro-inflammatory cytokines (Lee et al., 2007; Schink et al., 2018b; Liu et al., 2019; Weber et al., 2019). Moreover, hop and cinnamon extracts can inhibit angiogenesis, thrombosis, and vascular endothelialitis (Dorn et al., 2012; Saugspier et al., 2012; Xin et al., 2017; Patra et al., 2019). Further, these herbal extracts can activate the key regulator of the antioxidant response, NRF2, which mitigates the ROS/RNS production generally associated with inflammation (Dietz et al., 2005, 2013; Wondrak et al., 2010; Lee et al., 2011; Pinto et al., 2014; Long et al., 2015; Yao et al., 2015). Taken together, we suggest that hop and Ceylon cinnamon extracts may ameliorate complications that are associated with severe cases of COVID-19 and that testing both extracts, either alone or in combination, and particularly as a supplemental treatment to other medications, might be a promising therapeutic approach. If the preliminary results for dexamethasone can be confirmed, this glucocorticoid may be widely used to treat cases of COVID-19 (Horby et al., 2020). Supplementation with Ceylon cinnamon extract could then ameliorate the potential side effects of dexamethasone such as atherosclerosis (Nayak et al., 2017).

\section{REFERENCES}

Ackermann, M., Verleden, S. E., Kuehnel, M., Haverich, A., Welte, T., Laenger, F., et al. (2020). Pulmonary vascular endothelialitis, thrombosis, and angiogenesis in Covid-19. N. Engl. J. Med. 383, 120-128. doi: 10.1056/NEJMoa2015432

Aghamiri, V., Mirghafourvand, M., Mohammad-Alizadeh-Charandabi, S., and Nazemiyeh, H. (2016). The effect of Hop (Humulus lupulus L.) on early
Hop extracts exert anti-viral effects against some virus strains, but whether these extracts are also effective against SARS-CoV-2 has not yet been experimentally verified (Buckwold et al., 2004; Zhang et al., 2010; Fuchimoto et al., 2013).

Pneumonia caused by bacteria is a frequent complication after artificial ventilation (Póvoa et al., 2020; Wu et al., 2020; Zhang et al., 2020). The anti-bacterial effects of hops (Gerhäuser, 2005; Natarajan et al., 2008; Cermak et al., 2017; Weber et al., 2019) and Ceylon cinnamon (Ranasinghe et al., 2013; Vasconcelos et al., 2018; Doyle and Stephens, 2019) could act preventatively in such cases. As they are derived from common foodstuffs, both hop and Ceylon cinnamon extracts can be regarded as safe. Of course, an allergy against a hop or cinnamon ingredient or alcohol intolerance would contraindicate their intake.

It has become clear that many COVID-19 patients suffer from inflammatory complications (Heneka et al., 2020; Portincasa et al., 2020). We suggest that treatment with the herediscussed extracts could also mitigate such complications. Should cinnamon and hops prove to exert positive effects in the treatment of COVID-19, they would be readily available at low cost and can be produced at multi-ton scales. In western medicine, it is common to use pure substances rather than less well-defined herbal extracts. Of course, the individual compounds as listed in Table 1 can be used for treatment, but a certain loss of synergy may result (Schink et al., 2018a).

In conclusion, we recommend future experiments on hops and Ceylon cinnamon to evaluate their potential in limiting overshooting immune reactions in COVID-19. We work mainly with ethanolic extracts in cell culture. However, encapsulated cinnamon powder or water extracts of hops may be better suited for administration to patients. We suggest that appropriate doses for treatment of COVID-19 patients may be determined with reference to the clinical studies that have used hops and Ceylon cinnamon to treat other conditions.

\section{AUTHOR CONTRIBUTIONS}

KL and MA initiated the idea of the review and were involved in the manuscript writing. J-FN was involved in manuscript refinement. NO was involved in the literature search. All authors contributed to the article and approved the submitted version.

\section{ACKNOWLEDGMENTS}

We thank Ulrich Pöschl very much for his helpful support. menopausal symptoms and hot flashes: a randomized placebo-controlled trial. Complement. Ther. Clin. Pract. 23, 130-135. doi: 10.1016/j.ctcp.2015.05.001 Akilen, R., Tsiami, A., Devendra, D., and Robinson, N. (2010). Glycated haemoglobin and blood pressure-lowering effect of cinnamon in multi-ethnic Type 2 diabetic patients in the UK: a randomized, placebocontrolled, double-blind clinical trial. Diabet. Med. 27, 1159-1167. doi: 10.1111/j.1464-5491.2010.03079.x 
Altschuler, J. A., Casella, S. J., Mackenzie, T. A., and Curtis, K. M. (2007). The effect of cinnamon on $\mathrm{A} 1 \mathrm{C}$ among adolescents with type 1 diabetes. Diabetes Care 30, 813-816. doi: $10.2337 / \mathrm{dc} 06-1871$

Askari, F., Rashidkhani, B., and Hekmatdoost, A. (2014). Cinnamon may have therapeutic benefits on lipid profile, liver enzymes, insulin resistance, and highsensitivity C-reactive protein in nonalcoholic fatty liver disease patients. Nutr. Res. 34, 143-148. doi: 10.1016/j.nutres.2013.11.005

Azimi, P., Ghiasvand, R., Feizi, A., Hosseinzadeh, J., Bahreynian, M., Hariri, M., et al. (2016). Effect of cinnamon, cardamom, saffron, and ginger consumption on blood pressure and a marker of endothelial function in patients with type 2 diabetes mellitus: a randomized controlled clinical trial. Blood Press. 25, 133-140. doi: 10.3109/08037051.2015.1111020

Bernardo, M. A., Silva, M. L., Santos, E., Moncada, M. M., Brito, J., Proença, L., et al. (2015). Effect of cinnamon tea on postprandial glucose concentration. J. Diabetes Res. 2015:913651. doi: 10.1155/2015/913651

Borzoei, A., Rafraf, M., and Asghari-Jafarabadi, M. (2018). Cinnamon improves metabolic factors without detectable effects on adiponectin in women with polycystic ovary syndrome. Asia Pac. J. Clin. Nutr. 27, 556-563. doi: $10.6133 /$ apjen.062017.13

Buckwold, V. E., Wilson, R. J., Nalca, A., Beer, B. B., Voss, T. G., Turpin, J. A., et al. (2004). Antiviral activity of hop constituents against a series of DNA and RNA viruses. Antiviral Res. 61, 57-62. doi: 10.1016/S0166-3542(03)00155-4

Cermak, P., Olsovska, J., Mikyska, A., Dusek, M., Kadleckova, Z., Vanicek, J., et al. (2017). Strong antimicrobial activity of xanthohumol and other derivatives from hops (Humulus lupulus L.) on gut anaerobic bacteria. Apmis 125, 1033-1038. doi: 10.1111/apm.12747

Chen, L. L., Shen, Y. C., Ke, C. C., Imtiyaz, Z., Chen, H. I., Chang, C. H., et al. (2021). Efficacy of cinnamon patch treatment for alleviating symptoms of overactive bladder: a double-blind, randomized, placebo-controlled trial. Phytomedicine 80:153380. doi: 10.1016/j.phymed.2020.153380

Cornu, C., Remontet, L., Noel-Baron, F., Nicolas, A., Feugier-Favier, N., Roy, P., et al. (2010). A dietary supplement to improve the quality of sleep: a randomized placebo controlled trial. BMC Complement. Altern. Med. 10:29. doi: 10.1186/1472-6882-10-29

Crawford, P. (2009). Effectiveness of cinnamon for lowering hemoglobin A1C in patients with type 2 diabetes: a randomized, controlled trial. J. Am. Board Fam. Med. 22, 507-512. doi: 10.3122/jabfm.2009.05.080093

Dietz, B. M., Hagos, G. K., Eskra, J. N., Wijewickrama, G. T., Anderson, J. R., Nikolic, D., et al. (2013). Differential regulation of detoxification enzymes in hepatic and mammary tissue by hops (Humulus lupulus) in vitro and in vivo. Mol. Nutr. Food Res. 57, 1055-1066. doi: 10.1002/mnfr.201200534

Dietz, B. M., Kang, Y. H., Liu, G., Eggler, A. L., Yao, P., Chadwick, L. R., et al. (2005). Xanthohumol isolated from Humulus lupulus Inhibits menadioneinduced DNA damage through induction of quinone reductase. Chem. Res. Toxicol. 18, 1296-1305. doi: 10.1021/tx050058x

Dimpfel, W., and Suter, A. (2008). Sleep improving effects of a single dose administration of a valerian/hops fluid extract-a double blind, randomized, placebo-controlled sleep-EEG study in a parallel design using electrohypnograms. Eur. J. Med. Res. 13, 200-204. doi: 10.1055/s-2008-1047853

Dorn, C., Heilmann, J., and Hellerbrand, C. (2012). Protective effect of xanthohumol on toxin-induced liver inflammation and fibrosis. Int. J. Clin. Exp. Pathol. 5, 29-36. doi: 10.1055/s-0031-1295738

Doyle, A. A., and Stephens, J. C. (2019). A review of cinnamaldehyde and its derivatives as antibacterial agents. Fitoterapia 139:104405. doi: 10.1016/j.fitote.2019.104405

Erkkola, R., Vervarcke, S., Vansteelandt, S., Rompotti, P., De Keukeleire, D., and Heyerick, A. (2010). A randomized, double-blind, placebo-controlled, crossover pilot study on the use of a standardized hop extract to alleviate menopausal discomforts. Phytomedicine 17, 389-396. doi: 10.1016/j.phymed.2010.01.007

Ferk, F., Mišík, M., Nersesyan, A., Pichler, C., Jäger, W., Szekeres, T., et al. (2016). Impact of xanthohumol (a prenylated flavonoid from hops) on DNA stability and other health-related biochemical parameters: results of human intervention trials. Mol. Nutr. Food Res. 60, 773-786. doi: 10.1002/mnfr.201500355

Fu, W., Chen, L., Wang, Z., Zhao, C., Chen, G., Liu, X., et al. (2016). Determination of the binding mode for anti-inflammatory natural product xanthohumol with myeloid differentiation protein 2. Drug Des. Dev. Ther. 10, 455-463. doi: 10.2147/DDDT.S98466
Fuchimoto, J., Kojima, T., Okabayashi, T., Masaki, T., Ogasawara, N., Obata, K., et al. (2013). Humulone suppresses replication of respiratory syncytial virus and release of IL-8 and RANTES in normal human nasal epithelial cells. Med. Mol. Morphol. 46, 203-209. doi: 10.1007/s00795-013-0024-1

Gauruder-Burmester, A., Heim, S., Patz, B., and Seibt, S. (2019). Cucurbita pepoRhus aromatica-Humulus lupulus combination reduces overactive bladder symptoms in women-a noninterventional study. Planta Med. 85, 1044-1053. doi: 10.1055/a-0946-2280

Gerhard, U., Linnenbrink, N., Georghiadou, C., and Hobi, V. (1996). [Vigilancedecreasing effects of 2 plant-derived sedatives]. Praxis (Bern 1994) 85, 473-481.

Gerhäuser, C. (2005). Broad spectrum anti-infective potential of xanthohumol from hop (Humulus lupulus L.) in comparison with activities of other hop constituents and xanthohumol metabolites. Mol. Nutr. Food Res. 49, 827-831. doi: $10.1002 / \mathrm{mnfr} .200500091$

Gupta Jain, S., Puri, S., Misra, A., Gulati, S., and Mani, K. (2017). Effect of oral cinnamon intervention on metabolic profile and body composition of Asian Indians with metabolic syndrome: a randomized double-blind control trial. Lipids Health Dis. 16:113. doi: 10.1186/s12944-017-0504-8

Hajimonfarednejad, M., Nimrouzi, M., Heydari, M., Zarshenas, M. M., Raee, M. J., and Jahromi, B. N. (2018). Insulin resistance improvement by cinnamon powder in polycystic ovary syndrome: a randomized double-blind placebo controlled clinical trial. Phytother. Res. 32, 276-283. doi: 10.1002/ptr.5970

Hall, A. J., Babish, J. G., Darland, G. K., Carroll, B. J., Konda, V. R., Lerman, R. H., et al. (2008). Safety, efficacy, and anti-inflammatory activity of rho iso-alpha-acids from hops. Phytochemistry 69, 1534-1547. doi: 10.1016/j.phytochem.2008.02.001

Heneka, M. T., Golenbock, D., Latz, E., Morgan, D., and Brown, R. (2020). Immediate and long-term consequences of COVID-19 infections for the development of neurological disease. Alzheimers Res. Ther. 12:69. doi: 10.1186/s13195-020-00640-3

Horby, P., Lim, W. S., Emberson, J. R., Mafham, M., Bell, J. L., Linsell, L., et al. (2020). Dexamethasone in hospitalized patients with Covid-19-preliminary report. N. Engl. J. Med. doi: 10.1101/2020.06.22.20137273

Jahangirifar, M., Taebi, M., and Dolatian, M. (2018). The effect of cinnamon on primary dysmenorrhea: a randomized, double-blind clinical trial. Complement. Ther. Clin. Pract. 33, 56-60. doi: 10.1016/j.ctcp.2018.08.001

Kanuri, G., Weber, S., Volynets, V., Spruss, A., Bischoff, S. C., and Bergheim, I. (2009). Cinnamon extract protects against acute alcohol-induced liver steatosis in mice. J. Nutr. 139, 482-487. doi: 10.3945/jn.108.1 00495

Khan, A., Safdar, M., Ali Khan, M. M., Khattak, K. N., and Anderson, R. A. (2003). Cinnamon improves glucose and lipids of people with type 2 diabetes. Diabetes Care 26, 3215-3218. doi: 10.2337/diacare.26.12.3215

Knez Hrncic, M., Spaninger, E., Kosir, I. J., Knez, Z., and Bren, U. (2019). Hop compounds: extraction techniques, chemical analyses, antioxidative, antimicrobial, and anticarcinogenic effects. Nutrients 11:257. doi: 10.3390/nu11020257

Koetter, U., Schrader, E., Käufeler, R., and Brattström, A. (2007). A randomized, double blind, placebo-controlled, prospective clinical study to demonstrate clinical efficacy of a fixed valerian hops extract combination (Ze 91019) in patients suffering from non-organic sleep disorder. Phytother. Res. 21, 847-851. doi: $10.1002 /$ ptr.2167

Kort, D. H., and Lobo, R. A. (2014). Preliminary evidence that cinnamon improves menstrual cyclicity in women with polycystic ovary syndrome: a randomized controlled trial. Am. J. Obstet. Gynecol. 211, 487.e1-487.e6. doi: 10.1016/j.ajog.2014.05.009

Kyrou, I., Christou, A., Panagiotakos, D., Stefanaki, C., Skenderi, K., Katsana, K., et al. (2017). Effects of a hops (Humulus lupulus L.) dry extract supplement on self-reported depression, anxiety, and stress levels in apparently healthy young adults: a randomized, placebo-controlled, double-blind, crossover pilot study. Hormones (Athens) 16, 171-180. doi: 10.14310/horm.2002.1738

Lee, I. S., Lim, J., Gal, J., Kang, J. C., Kim, H. J., Kang, B. Y., et al. (2011). Antiinflammatory activity of xanthohumol involves heme oxygenase-1 induction via NRF2-ARE signaling in microglial BV2 cells. Neurochem. Int. 58, 153-160. doi: $10.1016 /$ j.neuint.2010.11.008

Lee, J. C., Kundu, J. K., Hwang, D. M., Na, H. K., and Surh, Y. J. (2007). Humulone inhibits phorbol ester-induced COX-2 expression in mouse skin by blocking activation of NF-kappaB and AP-1: IkappaB kinase and c-Jun-N-terminal 
kinase as respective potential upstream targets. Carcinogenesis 28, 1491-1498. doi: $10.1093 /$ carcin/bgm054

Lin, M., Xiang, D., Chen, X., and Huo, H. (2019). Role of characteristic components of humulus lupulus in promoting human health. J. Agric. Food Chem. 67, 8291-8302. doi: 10.1021/acs.jafc.9b03780

Liu, X., Bai, J., Jiang, C., Song, Z., Zhao, Y., Nauwynck, H., et al. (2019). Therapeutic effect of Xanthohumol against highly pathogenic porcine reproductive and respiratory syndrome viruses. Vet. Microbiol. 238:108431. doi: 10.1016/j.vetmic.2019.108431

Liu, Y., Cotillard, A., Vatier, C., Bastard, J. P., Fellahi, S., Stévant, M., et al. (2015). A dietary supplement containing cinnamon, chromium, and carnosine decreases fasting plasma glucose and increases lean mass in overweight or obese pre-diabetic subjects: a randomized, placebo-controlled trial. PLOS ONE 10:e0138646. doi: 10.1145/2818302

Long, M., Tao, S., Rojo De La Vega, M., Jiang, T., Wen, Q., Park, S. L., et al. (2015). Nrf2-dependent suppression of azoxymethane/dextran sulfate sodium-induced colon carcinogenesis by the cinnamon-derived dietary factor cinnamaldehyde. Cancer Prev. Res. (Phila) 8, 444-454. doi: 10.1158/1940-6207.CAPR-14-0359

Lu, J., Zhang, K., Nam, S., Anderson, R. A., Jove, R., and Wen, W. (2010). Novel angiogenesis inhibitory activity in cinnamon extract blocks VEGFR2 kinase and downstream signaling. Carcinogenesis 31, 481-488. doi: 10.1093/carcin/bgp292

Lu, T., Sheng, H., Wu, J., Cheng, Y., Zhu, J., and Chen, Y. (2012). Cinnamon extract improves fasting blood glucose and glycosylated hemoglobin level in Chinese patients with type 2 diabetes. Nutr. Res. 32, 408-412. doi: 10.1016/j.nutres.2012.05.003

Lucas, K., and Maes, M. (2013). Role of the Toll Like receptor (TLR) radical cycle in chronic inflammation: possible treatments targeting the TLR4 pathway. Mol. Neurobiol. 48, 190-204. doi: 10.1007/s12035-013-8425-7

Mang, B., Wolters, M., Schmitt, B., Kelb, K., Lichtinghagen, R., Stichtenoth, D. O., et al. (2006). Effects of a cinnamon extract on plasma glucose, HbA, and serum lipids in diabetes mellitus type 2. Eur. J. Clin. Invest. 36, 340-344. doi: $10.1111 / j .1365-2362.2006 .01629 . x$

Maroo, N., Hazra, A., and Das, T. (2013). Efficacy and safety of a polyherbal sedative-hypnotic formulation NSF-3 in primary insomnia in comparison to zolpidem: a randomized controlled trial. Indian J. Pharmacol. 45, 34-39. doi: 10.4103/0253-7613.106432

Minich, D. M., Bland, J. S., Katke, J., Darland, G., Hall, A., Lerman, R. H., et al. (2007). Clinical safety and efficacy of NG440: a novel combination of rho iso-alpha acids from hops, rosemary, and oleanolic acid for inflammatory conditions. Can. J. Physiol. Pharmacol. 85, 872-883. doi: 10.1139/Y07-055

Mirmiran, P., Davari, M., Hashemi, R., Hedayati, M., Sahranavard, S., Bahreini, S., et al. (2019). A randomized controlled trial to determining the effect of cinnamon on the plasma levels of soluble forms of vascular adhesion molecules in type 2 diabetes mellitus. Eur. J. Clin. Nutr. 73, 1605-1612. doi: 10.1038/s41430-019-0523-9

Mohammadi, A., Mohammad-Alizadeh-Charandabi, S., Mirghafourvand, M., Javadzadeh, Y., Fardiazar, Z., and Effati-Daryani, F. (2014). Effects of cinnamon on perineal pain and healing of episiotomy: a randomized placebo-controlled trial. J. Integr. Med. 12, 359-366. doi: 10.1016/S2095-4964(14)60025-X

Morimoto-Kobayashi, Y., Ohara, K., Ashigai, H., Kanaya, T., Koizumi, K., Manabe, F., et al. (2016). Matured hop extract reduces body fat in healthy overweight humans: a randomized, double-blind, placebo-controlled parallel group study. Nutr. J. 15:25. doi: 10.1186/s12937-016-0144-2

Müller-Limmroth, W., and Ehrenstein, W. (1977). [Experimental studies of the effects of Seda-Kneipp on the sleep of sleep disturbed subjects; implications for the treatment of different sleep disturbances (author's transl)]. Med. Klin. 72, $1119-1125$.

Natarajan, P., Katta, S., Andrei, I., Babu Rao Ambati, V., Leonida, M., and Haas, G. J. (2008). Positive antibacterial co-action between hop (Humulus lupulus) constituents and selected antibiotics. Phytomedicine 15, 194-201. doi: 10.1016/j.phymed.2007.10.008

Nayak, I. N., Chinta, R., and Jetti, R. (2017). Anti-atherosclerotic potential of aqueous extract of cinnamomum zeylanicum Bark against glucocorticoid induced atherosclerosis in wistar rats. J. Clin. Diagn. Res. 11, Fc19-fc23. doi: $10.7860 / J C D R / 2017 / 23910.9864$

Nir, Y., Potasman, I., Stermer, E., Tabak, M., and Neeman, I. (2000). Controlled trial of the effect of cinnamon extract on Helicobacter pylori. Helicobacter 5, 94-97. doi: 10.1046/j.1523-5378.2000.00014.x
Oketch-Rabah, H. A., Marles, R. J., and Brinckmann, J. A. (2018). Cinnamon and cassia nomenclature confusion: a challenge to the applicability of clinical data. Clin. Pharmacol. Ther. 104, 435-445. doi: 10.1002/cpt.1162

Ose, R., Tu, J., Schink, A., Maxeiner, J., Schuster, P., Lucas, K., et al. (2020). Cinnamon extract inhibits allergen-specific immune responses in human and murine allergy models. Clin. Exp. Allergy 50, 41-50. doi: 10.1111/cea.13507

Palamand, S. R., and Aldenhoff, J. M. (1973). Bitter tasting compounds of beer. Chemistry and taste properties of some hop resin compounds. J. Agric. Food Chem. 21, 535-543. doi: 10.1021/jf60188a005

Patra, K., Jana, S., Sarkar, A., Mandal, D. P., and Bhattacharjee, S. (2019). The inhibition of hypoxia-induced angiogenesis and metastasis by cinnamaldehyde is mediated by decreasing HIF-1 $\alpha$ protein synthesis via PI3K/Akt pathway. Biofactors 45, 401-415. doi: 10.1002/biof.1499

Pender, D. N., Crawford, P. F., Clark, J. M., Crawford, A. J., Prats, A. A., and Shah, S. A. (2018). Effect of water-soluble cinnamon extract on electrocardiographic parameters: an analysis of the CiNNaMON trial. Complement. Ther. Med. 41, 302-305. doi: 10.1016/j.ctim.2018.10.009

Pinto, C., Cestero, J. J., Rodríguez-Galdón, B., and Macías, P. (2014). Xanthohumol, a prenylated flavonoid from hops (Humulus lupulus L.), protects rat tissues against oxidative damage after acute ethanol administration. Toxicol. Rep. 1, 726-733. doi: 10.1016/j.toxrep.2014.09.004

Portincasa, P., Krawczyk, M., Machill, A., Lammert, F., and Di Ciaula, A. (2020). Hepatic consequences of COVID-19 infection. Lapping or biting? Eur. J. Intern. Med. 77, 18-24. doi: 10.1016/j.ejim.2020.05.035

Possemiers, S., Bolca, S., Grootaert, C., Heyerick, A., Decroos, K., Dhooge, W., et al. (2006). The prenylflavonoid isoxanthohumol from hops (Humulus lupulus L.) is activated into the potent phytoestrogen 8-prenylnaringenin in vitro and in the human intestine. J. Nutr. 136, 1862-1867. doi: 10.1093/jn/136.7.1862

Póvoa, H. C. C., Chianca, G. C., and Iorio, N. (2020). COVID-19: an alert to ventilator-associated bacterial pneumonia. Infect. Dis. Ther. 9, 1-4. doi: 10.1007/s40121-020-00306-5

Ranasinghe, P., Galappaththy, P., Constantine, G. R., Jayawardena, R., Weeratunga, H. D., Premakumara, S., et al. (2017a). Cinnamomum zeylanicum (Ceylon cinnamon) as a potential pharmaceutical agent for type-2 diabetes mellitus: study protocol for a randomized controlled trial. Trials 18:446. doi: 10.1186/s13063-017-2192-0

Ranasinghe, P., Jayawardena, R., Pigera, S., Wathurapatha, W. S., Weeratunga, H. D., Premakumara, G., et al. (2017b). Evaluation of pharmacodynamic properties and safety of Cinnamomum zeylanicum (Ceylon cinnamon) in healthy adults: a phase I clinical trial. BMC Complement. Altern. Med. 17:550. doi: 10.1186/s12906-017-2067-7

Ranasinghe, P., Pigera, S., Premakumara, G. A., Galappaththy, P., Constantine, G. R., and Katulanda, P. (2013). Medicinal properties of 'true' cinnamon (Cinnamomum zeylanicum): a systematic review. BMC Complement. Altern. Med. 13:275. doi: 10.1186/1472-6882-13-275

Renu, K., Prasanna, P. L., and Valsala Gopalakrishnan, A. (2020). Coronaviruses pathogenesis, comorbidities, and multi-organ damage-a review. Life Sci. 255:117839. doi: 10.1016/j.lfs.2020.117839

Roussel, A. M., Hininger, I., Benaraba, R., Ziegenfuss, T. N., and Anderson, R. A. (2009). Antioxidant effects of a cinnamon extract in people with impaired fasting glucose that are overweight or obese. J. Am. Coll. Nutr. 28, 16-21. doi: $10.1080 / 07315724.2009 .10719756$

Saugspier, M., Dorn, C., Thasler, W. E., Gehrig, M., Heilmann, J., and Hellerbrand, C. (2012). Hop bitter acids exhibit anti-fibrogenic effects on hepatic stellate cells in vitro. Exp. Mol. Pathol. 92, 222-228. doi: 10.1016/j.yexmp.2011.11.005

Schink, A., Naumoska, K., Kitanovski, Z., Kampf, C. J., Fröhlich-Nowoisky, J., Thines, E., et al. (2018a). Anti-inflammatory effects of cinnamon extract and identification of active compounds influencing the TLR2 and TLR4 signaling pathways. Food Funct. 9, 5950-5964. doi: 10.1039/C8FO01286E

Schink, A., Neumann, J., Leifke, A. L., Ziegler, K., Fröhlich-Nowoisky, J., Cremer, C., et al. (2018b). Screening of herbal extracts for TLR2and TLR4-dependent anti-inflammatory effects. PLOS ONE 13:e0203907. doi: 10.1371/journal.pone.0203907

Shinada, K., Tagashira, M., Watanabe, H., Sopapornamorn, P., Kanayama, A., Kanda, T., et al. (2007). Hop bract polyphenols reduced three-day dental plaque regrowth. J. Dent. Res. 86, 848-851. doi: 10.1177/154405910708600908

Stevens, J. F., Miranda, C. L., Wolthers, K. R., Schimerlik, M., Deinzer, M. L., and Buhler, D. R. (2002). Identification and in vitro biological activities of 
hop proanthocyanidins: inhibition of nNOS activity and scavenging of reactive nitrogen species. J. Agric. Food Chem. 50, 3435-3443. doi: 10.1021/jf0116202

Suzuki, S., Yamazaki, T., Takahashi, C., Kaneko, Y., Morimoto-Kobayashi, Y., and Katayama, M. (2018). The relationship between the effect of matured hop extract and physical activity on reducing body fat: re-analysis of data from a randomized, double-blind, placebo-controlled parallel group study. Nutr. J. 17:98. doi: 10.1186/s12937-018-0405-3

Talaei, B., Amouzegar, A., Sahranavard, S., Hedayati, M., Mirmiran, P., and Azizi, F. (2017). Effects of cinnamon consumption on glycemic indicators, advanced glycation end products, and antioxidant status in type 2 diabetic patients. Nutrients 9:991. doi: 10.3390/nu9090991

Tomita, J., Mochizuki, S., Fujimoto, S., Kashihara, N., Akasaka, T., Tanimoto, M., et al. (2017). Acute improvement of endothelial functions after oral ingestion of isohumulones, bitter components of beer. Biochem. Biophys. Res. Commun. 484, 740-745. doi: 10.1016/j.bbrc.2017.01.133

van Breemen, R. B., Chen, L., Tonsing-Carter, A., Banuvar, S., Barengolts, E., Viana, M., et al. (2020). Pharmacokinetic interactions of a hop dietary supplement with drug metabolism in perimenopausal and postmenopausal women. J. Agric. Food Chem. 68, 5212-5220. doi: 10.1021/acs.jafc.0c01077

Vanschoonbeek, K., Thomassen, B. J., Senden, J. M., Wodzig, W. K., and Van Loon, L. J. (2006). Cinnamon supplementation does not improve glycemic control in postmenopausal type 2 diabetes patients. J. Nutr. 136, 977-980. doi: $10.1093 /$ in $/ 136.4 .977$

Vasconcelos, N. G., Croda, J., and Simionatto, S. (2018). Antibacterial mechanisms of cinnamon and its constituents: a review. Microb. Pathog. 120, 198-203. doi: 10.1016/j.micpath.2018.04.036

Wainstein, J., Stern, N., Heller, S., and Boaz, M. (2011). Dietary cinnamon supplementation and changes in systolic blood pressure in subjects with type 2 diabetes. J. Med. Food 14, 1505-1510. doi: 10.1089/jmf.2010.0300

Walker, E., Lo, K., Tham, S., Pahl, M., Lomiwes, D., Cooney, J., et al. (2019). New Zealand bitter hops extract reduces hunger during a $24 \mathrm{~h}$ water only fast. Nutrients 11:2754. doi: 10.3390/nu11112754

Wang, T., Du, Z., Zhu, F., Cao, Z., An, Y., Gao, Y., et al. (2020). Comorbidities and multi-organ injuries in the treatment of COVID-19. Lancet 395:e52. doi: 10.1016/S0140-6736(20)30558-4

Weber, N., Biehler, K., Schwabe, K., Haarhaus, B., Quirin, K. W., Frank, U., et al. (2019). Hop extract acts as an antioxidant with antimicrobial effects against propionibacterium acnes and staphylococcus aureus. Molecules 24:223. doi: $10.3390 /$ molecules 24020223

Wickenberg, J., Lindstedt, S., Berntorp, K., Nilsson, J., and Hlebowicz, J. (2012). Ceylon cinnamon does not affect postprandial plasma glucose or insulin in subjects with impaired glucose tolerance. Br. J. Nutr. 107, 1845-1849. doi: $10.1017 /$ S0007114511005113

Wondrak, G. T., Villeneuve, N. F., Lamore, S. D., Bause, A. S., Jiang, T., and Zhang, D. D. (2010). The cinnamon-derived dietary factor cinnamic aldehyde activates the Nrf2-dependent antioxidant response in human epithelial colon cells. Molecules 15, 3338-3355. doi: 10.3390/molecules15053338
Wu, C. P., Adhi, F., and Highland, K. (2020). Recognition and management of respiratory coinfection and secondary bacterial pneumonia in patients with COVID-19. Cleve. Clin. J. Med. 87, 659-663. doi: 10.3949/ccjm.87a.ccc015

Xin, G., Wei, Z., Ji, C., Zheng, H., Gu, J., Ma, L., et al. (2017). Xanthohumol isolated from Humulus lupulus prevents thrombosis without increased bleeding risk by inhibiting platelet activation and mtDNA release. Free Radic. Biol. Med. 108, 247-257. doi: 10.1016/j.freeradbiomed.2017.02.018

Yamamoto, K., Wang, J., Yamamoto, S., and Tobe, H. (2000). Suppression of cyclooxygenase-2 gene transcription by humulon of beer hop extract studied with reference to glucocorticoid. FEBS Lett. 465, 103-106. doi: 10.1016/S0014-5793(99)01727-5

Yamamoto, M., Kensler, T. W., and Motohashi, H. (2018). The KEAP1NRF2 system: a thiol-based sensor-effector apparatus for maintaining redox homeostasis. Physiol. Rev. 98, 1169-1203. doi: 10.1152/physrev.00023.2017

Yao, J., Zhang, B., Ge, C., Peng, S., and Fang, J. (2015). Xanthohumol, a polyphenol chalcone present in hops, activating Nrf2 enzymes to confer protection against oxidative damage in PC12 cells. J. Agric. Food Chem. 63, 1521-1531. doi: $10.1021 / \mathrm{j} 5505075 \mathrm{n}$

Ye, Q., Wang, B., and Mao, J. (2020). The pathogenesis and treatment of the "Cytokine Storm" in COVID-19. J. Infect. 80, 607-613. doi: $10.1016 /$ j.jinf.2020.03.037

Zare, R., Nadjarzadeh, A., Zarshenas, M. M., Shams, M., and Heydari, M. (2019). Efficacy of cinnamon in patients with type II diabetes mellitus: a randomized controlled clinical trial. Clin. Nutr. 38, 549-556. doi: 10.1016/j.clnu.2018.03.003

Zareie, A., Sahebkar, A., Khorvash, F., Bagherniya, M., Hasanzadeh, A., and Askari, G. (2020). Effect of cinnamon on migraine attacks and inflammatory markers: a randomized double-blind placebo-controlled trial. Phytother. Res. 34, 2945-2952. doi: 10.1002/ptr.6721

Zhang, H., Zhang, Y., Wu, J., Li, Y., Zhou, X., Li, X., et al. (2020). Risks and features of secondary infections in severe and critical ill COVID-19 patients. Emerg. Microbes Infect. 9, 1958-1964. doi: 10.1080/22221751.2020.1812437

Zhang, N., Liu, Z., Han, Q., Chen, J., and Lv, Y. (2010). Xanthohumol enhances antiviral effect of interferon $\alpha-2 b$ against bovine viral diarrhea virus, a surrogate of hepatitis C virus. Phytomedicine 17, 310-316. doi: 10.1016/j.phymed.2009.08.005

Conflict of Interest: The authors declare that the research was conducted in the absence of any commercial or financial relationships that could be construed as a potential conflict of interest.

Copyright (๑ 2021 Lucas, Fröhlich-Nowoisky, Oppitz and Ackermann. This is an open-access article distributed under the terms of the Creative Commons Attribution License (CC BY). The use, distribution or reproduction in other forums is permitted, provided the original author(s) and the copyright owner(s) are credited and that the original publication in this journal is cited, in accordance with accepted academic practice. No use, distribution or reproduction is permitted which does not comply with these terms. 